\title{
IDENTIFIKASI KEMAMPUAN LITERASI KELAUTAN SISWA SEKOLAH MENENGAH PERTAMA (SMP) DI KAWASAN EKONOMI KHUSUS (KEK) MANDALIKA, LOMBOK TENGAH
}

\author{
Fahira Putri Utami*, Karnan, Baiq Sri Handayani, Mahrus \\ Prodi Pendidikan Biologi, Universitas Mataram \\ *Corresponding Author: fahiraaputri21@gmail.com
}

\section{Article History}

Received : April 23 ${ }^{\text {th }}, 2021$

Revised : April 27 $7^{\text {th }}, 2021$

Accepted : May 05 $5^{\text {th }}, 2021$

Published : May $10^{\text {th }}, 2021$

\begin{abstract}
Abstrak: Kawasan Ekonomi Khusus (KEK) Mandalika menjadi salah satu destinasi wisata utama yang memiliki panorama pesisir dan potensi sumberdaya laut yang melimpah, jika tidak dikelola dengan baik maka sumberdaya lautan akan mengalami kerusakan untuk itu sumberdaya manusia yang 'melek' akan lautan menjadi peran penting untuk mengelola sumberdaya pesisir dan lautan secara berkelanjutan. Tujuan dari penelitian ini adalah untuk mengidentifikasi kemampuan literasi kelautan siswa berdasarkan kompetensi 7 prinsip literasi kelautan pada sekolah menengah pertama di Kawasan Ekonomi Khusus (KEK) Mandalika, Lombok Tengah. Sample sekolah penelitian adalah SMP 1 Pujut, SMP 7 Pujut, Mts AlIjtihad, Mts Al-Irsyad dan Mts Nw Prabu. Penelitian dilakukan pada siswa kelas 9 dengan jumlah total 150 siswa. Metode penelitian yang digunakan pada penelitian ini adalah metode penelitian dekriptif. Hasil penelitian kemampuan literasi kelautan siswa dengan nilai presentase setiap sekolah yakni, SMP 1 Pujut sebesar 30\%, SMP 7 Pujut sebesar 34.41, Mts Al-Irsyad sebesar 27.58\%, Mts Al-Ijtihad sebesar 29.58\%, dan Mts Nw Prabu sebesar $25.83 \%$. Berdasarkan hasil rata-rata presentase tes literasi kelautan sebesar $29 \%$ dapat di simpulkan bahwa kemampuan literasi kelautan siswa sekolah menengah pertama (SMP) di Kawasan Ekonomi Khusus (KEK) Mandalika, Lombok Tengah dikategorikan rendah. Upaya untuk meningkatkan kemampuan literasi kelautan siswa guru dapat melakukan pengembangan materi dengan mengimplementasikan 7 prinsip literasi kelautan dalam proses pembelajaran.
\end{abstract}

Kata Kunci: Literasi Kelautan, Kebaharian, Konservasi, Pariwisata, KEK Mandalika.

\section{PENDAHULUAN}

Secara geografis Indonesia merupakan Negara bahari dengan dua pertiga luas lautan lebih besar daripada daratan, yang di kelilingi oleh pulau-pulau dengan kekayaan sumberdaya alam dan keanekaragaman hayati yang beragam. Potensi sumberdaya laut dan pesisir Indonesia sangat besar, bagi kehidupan masyarakat di Indonesia sejak dahulu.

Potensi sumberdaya pesisir dan laut yang dimiliki Indonesia salah satunya adalah potensi terumbu karang dimana terumbu karang mempunyai fungsi yang penting, antara lain sebagai penahan ombak dan pelindung pantai dari abrasi, tempat berkumpul dan berkembang biaknya ikan-ikan dan biota laut. Sebagaimana terumbu karang, padang lamun menjadi tempat yang paling produktif dengan keanekaragaman hayari yang relatif tinggi. Selain terumbu karang dan padang lamun Indonesia memiliki keanekaragaman jenis ikan yang bernilai ekonomis tinggi.

Kekayaan sumberdaya laut tersebut menimbulkan daya tarik untuk berbagai pihak untuk memanfaatkan sumberdaya dan keindahan panoramanya. Akan tetapi, dengan berkembangnya zaman kekayaan sumberdaya kelautan telah mengalami kerusakan. Faktor utama dalam kerusakan sumberdaya lautan yaitu faktor manusia diantaranya penangkapan ikan menggunakan bahan peledak, pemanfaatan berlebih atau over exploitation, pencemaran sampah dan limbah, dan juga perubahan fisik habitat, contohnya hutan mangrove berbagai daerah di Indonesia yang telah mengalami penurunnan luas dari tahun ke tahun. Degradasi tersebut akibat adanya konversi hutan mangrove untuk lahan tambak, pertanian, pemukiman, pelabuhan, dan industri wisata. Salah satu tempat 
di pulau Lombok yang sedang gencarnya pembangunan pada sektor pariwisata adalah KEK Mandalika, Lombok Tengah.

Kawasan Ekonomi Khusus (KEK) Mandalika menjadi salah satu tempat destinasi wisata yang terletak di bagian Selatan Pulau Lombok. KEK Mandalika ditetapkan melalui Peraturan Pemerintah Nomor 52 Tahun 2014 untuk menjadi KEK Pariwisata. Dengan luas area sebesar 1.035,67 Ha dan berhadapan langsung dengan Samudera Hindia, KEK Mandalika mejadi sektor pariwisata Provinsi Nusa Tenggara Barat yang sangat potensial. Hal ini menjadi daya tarik yang sangat besar bagi perusahaan untuk mengembangkan sektor pariwisata yang diperkirakan akan menarik 2 juta kunjungan wisatawan mancanegara. Harus disadari bahwa sumberdaya pesisir dan kelautan jika tidak dikelola dengan baik maka akan mengalami kerusakan dan kerugian yang besar.

Sumberdaya manusia yang melek akan lautan menjadi peran penting untuk mengelola sumberdaya pesisir dan kelautan secara berkelanjutan. Menurut (Fauville et al., 2019) seseorang dapat dikatakan memiliki literasi kelautan yang baik jika memahami prinsip penting dan konsep dasar tentang fungsi lautan, mampu berkomunikasi tentang lautan, mampu membuat keputusan yang tepat dan dapat bertanggung jawab terhadap lautan. Literasi kelautan meliputi prinsip-prinsip literasi ilmiah yang didefinisikan oleh standar nasional sebagai kemampuan untuk membuat keputusan berdasarkan informasi tentang masalah ilmiah kepentingan sosial tertentu (National Research Council, 2000). Berdasarkan hasil observasi pada siswa SMP di sekitar daerah pantai KEK Mandalika terhadap pemahaman siswa tentang lautan diperoleh informasi bahwa pemahaman siswa tentang lautan masih mengartikan laut tempat hidup ikan dan sebagai sumber pendapatan bagi para nelayan. Observasi tersebut menunjukan literasi kelautan yang dimiliki siswa masih terbatas.

Pemahaman tentang pengetahuan lautan yang masih terbatas sehingga masyarakat di sekitar daerah pantai tidak memahami bahwa tindakan sehari-hari yang dilakukan seperti berperahu, membuang limbah atau sampah tidak pada tempatnya, mengambil biota intertidal atau madak saat air surut, dapat berdampak pada ekosistem laut dan sumberdayanya. Menurut Greely (2018) laut saling terkait erat dengan kehidupan kegiatan sehari-hari masyarakat termasuk siswa di daerah pesisir sehingga saling ketergantungan antara manusia dan lautan adalah jantung dari literasi kelautan (Greely, 2008).

Pengetahuan tentang lautan sangat penting sehingga kebutuhan akan literasi kelautan menjadi faktor yang penting dan relevan untuk persiapan siswa, guru, dan masyarakat luas untuk ikut berkontribusi. Salah satu upaya yang dapat dilakukan sebagai pendidik yaitu untuk memberikan wawasan kelautan disekolah dengan integrasi ilmu kelautan ke dalam mata pelajaran terkait seperti biologi dan juga geografi. Langkah awal yang dapat dilakukan adalah mengetahui kemampuan literasi kelautan siswa adalah menyediakan instrumen literasi kelautan yang valid dan reliabel. Instrumen yang sudah valid dapat digunakan untuk menilai hasil pendidikan (Rusilowati et al., 2016). Berdasarkan uraian di atas, penulis melakukan penelitian yang dirumuskan dalam judul Identifikasi Kemampuan Literasi Kelautan Siswa SMP di Kawasan Ekonomi Khusus (KEK) Mandalika, Lombok Tengah.

\section{METODE}

\section{Tempat dan Waktu}

Penelitian ini dilaksanakan di 5 SMP pada Kawasan Ekonomi Khusus (KEK) Mandalika, Lombok Tengah, Nusa Tenggara Barat, yaitu SMP 1 Pujut, SMP 7 Pujut, Mts Al-Ijtihad, Mts Al-Irsyad, dan Mts Nw Prabu. Waktu penelitian dilaksanakan pada semester ganjil tahun ajaran 2020/2021 di bulan Oktober 2020.

\section{Data dan Analisis}

Jenis penelitian yang digunakan adalah penelitian kuantitatif deskriptif. Populasi pada penelitian ini adalah siswa sekolah menengah pertama di Kawasan Ekonomi Khusus (KEK) Mandalika dengan jumlah total dari 52 sekolah. Pemilihan sampel dalam penelitian ini menggunakan teknik random sampling. Sample dari penelitian ini diambil 5 (lima) sekolah menengah pertama (SMP) yang terdapat pada setiap titik pengambilan. Setiap sekolah akan diambil 30 orang siswa kelas tinggi sebagai sample, sehingga secara keseluruhan akan didapatkan 150 orang siswa sample.

Teknik pengumpulan data digunakan instrumen tes yang berupa tes tulis dalam bentuk soal pilihan ganda berjumlah 40 butir yang mengacu pada 7 prinsip literasi kelautan dan Greely, T. (2008). Ocean literacy and reasoning about ocean issues: The influence of content, experience and morality lalu di modifikasi sesuai 
dengan Kompetensi Dasar Kurikulum 2013 SMP.

Identifikasi data kemampuan literasi kelautan merupakan hasil posttest siswa yang dilakukan pada akhir pembelajaran atau setelah pembelajaran selesai. Menurut (Ali, 2013) kemampuan literasi sains dideskripsikan dengan menggunakan rumus sebagai berikut.

$$
\mathrm{S}=\mathrm{R} / \mathrm{N} \times 100
$$

Keterangan :

$$
\begin{aligned}
& \mathrm{S}=\text { Nilai kemampuan literasi sains siswa } \\
& \mathrm{R}=\text { Jumlah soal yang dijawab benar } \\
& \mathrm{N} \text { = Jumlah keseluruhan soal tes }
\end{aligned}
$$

Kemampuan literasi sains memiliki presentase nilai siswa yang dikelompokkan ke dalam kriteria hasil modifikasi dari (Purwanto, 2010).

Tabel 1. Kriteria Presentase Penilaian Kemampuan Literasi Sains Siswa

\begin{tabular}{|c|c|c|}
\hline No & Interval & Kriteria \\
\hline 1 & $86-100 \%$ & Sangat Tinggi \\
\hline 2 & $76-85 \%$ & Tinggi \\
\hline 3 & $60-75 \%$ & Cukup \\
\hline 4 & $55-59 \%$ & Rendah \\
\hline 5 & $\leq 54 \%$ & Sangat rendah \\
\hline \multicolumn{3}{|c|}{ (Purwanto, 2013) }
\end{tabular}

\section{HASIL DAN PEMBAHASAN}

\section{Nilai Literasi Kelautan Siswa}

Penelitian ini mengidentifikasi tingkat literasi kelautan dengan memberikan angket instrumen tes yang sejalan dengan 7 prinsip penting literasi kelautan. Prinsip-prinsip penting ini adalah: 1) Lautan di bumi merupakan satu kesatuan yang memiliki banyak karakteristik; 2) Lautan dan kehidupan di dalamnya membentuk karakteristik bumi; 3) Lautan adalah faktor penentu cuaca dan iklim; 4) Adanya lautan adalah alasan mengapa bumi dapat ditinggali; 5) Lautan memiliki kekayaan biodiversitas dan ekosistem yang besar; 6) Lautan dan manusia memiliki hubugan yang tidak terpisahkan, 7) Lautan masih belum banyak terekplorasi. Instrumen tes mengekspolrasi tingkat pengetahuan siswa tentang kelautan dengan menerapkan 7 prinsip penting literasi laut (Cava et al., 2005).

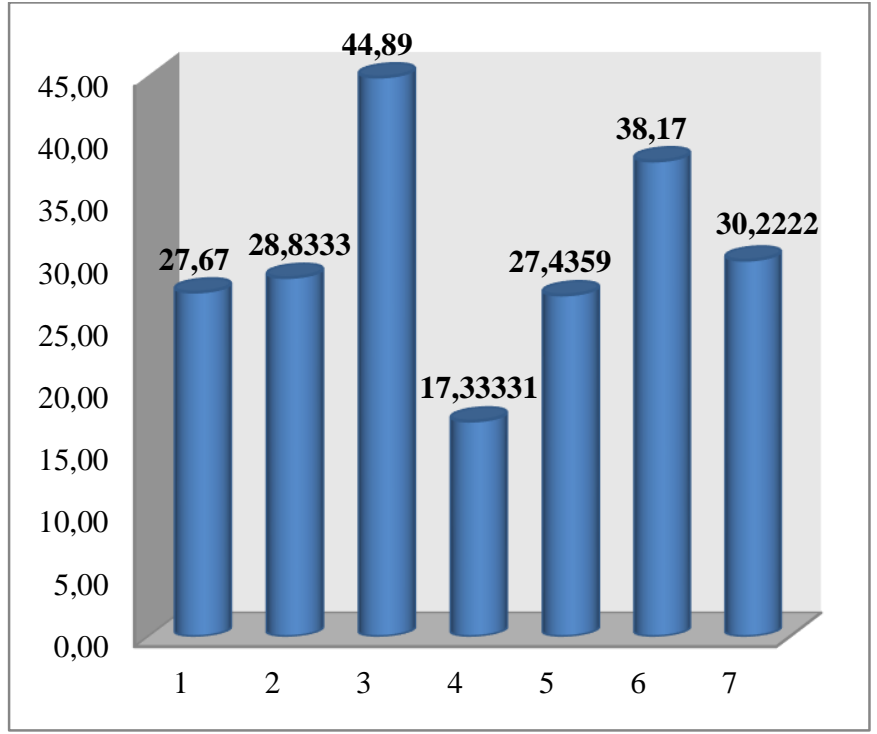

\section{Gambar 1. Rerata Hasil Literasi Siswa Pada 7 Prinsip Essential Literasi Kelautan}

Berdasarkan 7 prinsip kelautan pada gambar 4.1 prinsip 3 "lautan adalah faktor penentu cuaca dan iklim" memiliki nilai rata-rata tertinggi yakni 44,89. Prinsip ini sesuai dengan KD 3.5 IPA kelas VII yakni, menganalisis konsep suhu, pemuaian, kalor, perpindahan kalor dan penerapannya di kehidupan sehari-hari termasuk mekanisme menjaga kestabilan suhu tubuh pada manusia dan hewan. Rata-rata siswa pada setiap sekolah mampu menjawab soal nomor 2,13, dan 35 dengan benar. Setiap siswa mampu memahami dan menjelaskan bahwa lautan menjadi faktor penentu dari cuaca dan iklim dari suatu wilayah. Hal ini disebabkan karena cuaca dan iklim dapat diamati dan dirasakan langsung perubahannya oleh siswa sehingga mereka mampu mendeskripsikan atau menunjukan gejala-gejala perubahan cuaca dan iklim yang terjadi. Hal ini karena siswa menggunakan panca indranya sehingga otak mampu lebih memahami pembelajaran yang diberikan. Menurut Handayani (2017) pembelajaran dengan mengenal prinsip belajar anak yang terdiri dari tiga bagian: visual, verbal dan kinestetik. Iklim dan cuaca adalah materi yang sudah diajarkan kepada siswa sekolah dasar dalam sistem pendidikan Indonesia tepatnya pada kurikulum 2013. Pentingnya membelajarkan siswa tentang iklim dan cuaca menurut Yulianto (2020) mempelajari iklim dan cuaca menjadikan anak lebih mengenal lingkungan sekitarnya. Siswa dapat mengamati cuaca melalui awan, karena awan memberikan pengaruh terhadap perubahan cuaca dan iklim. Cuaca dan iklim juga berdampak pada perpindahan ikan-ikan di laut. 
Hal ini diperkuat dengan pernyataan (Isdianto, 2019) bahwa dampak sosisal ekonomi yang disebabkan oleh perubahan iklim adalah sulitnya menentukan posisi atau wilayah penangkapan ikan. Iklim maupun cuaca merupakan faktor yang berpengaruh dalam aktifitas sehari-hari (Kolsiana, 2017).

Sedangkan prinsip 4 "adanya lautan adalah alasan mengapa bumi dapat ditinggali" menjadi skor terendah dengan nilai rata-rata 17,33. Prinsip ini sesuai dengan KD 3.1 IPS di kelas VII yakni, memahami konsep ruang (lokasi, distribusi, potensi, iklim, bentuk muka bumi, geologis, flora, dan fauna) dan interaksi antar ruang di Indonesia serta pengaruhnya terhadap kehidupan manusia dalam aspek ekonomi, sosial, budaya, dan pendidikan. Nilai rata-rata dari prinsip 4 menunjukan siswa memiliki kesulitan dalam memahami dan memvisualisaikan bahwa laut dapat menjadikan bumi layak huni. Beberapa hal yang menyebabkan rendahnya hasil siswa pada prinsip 4 yakni siswa belum memperoleh ilmu atau materi tentang kelautan, sehingga siswa belum memahami tentang bagaimana terbentuknya lautan, bagian-bagian lautan, jenisjenis lautan dan fungsi dari lautan. Dalam bukubuku pembelajaran siswa sekolah menengah pertama tidak ditemukan materi yang mendalam tentang lautan. Sehingga pemahaman siswa masih sangat terbatas. Hal ini di dukung oleh pernyataan (Baransano, 2011) adanya wawasan tentang lautan akan mendukung setiap individu untuk menyadaro pentingnya lautan terhadap kehidupan. Hal ini diperkuat oleh (Irawan, 2018) bahwa pengetahuan tentang lautan dapat diintegrasikan kedalam mata pelajaran terkait contohnya biologo dengan deukungan guru yang dapat mengembangkan proses pembelajaran.

\section{Tabel 2. Presentase Hasil Literasi Kelautan} Siswa Sekolah Sample

\begin{tabular}{|c|c|}
\hline Sekolah & $\begin{array}{c}\text { Hasil Rata- } \\
\text { Rata }\end{array}$ \\
\hline SMP 1 PUJUT & 30,00 \\
\hline SMP 7 PUJUT & 34,42 \\
\hline Mts Al-Ijtihad & 29,58 \\
\hline Mts Al-Irsyad & 27,50 \\
\hline Mts Nw & 25.83 \\
\hline Rerata : & $\mathbf{2 9 \%}$ \\
\hline
\end{tabular}

Berdasarkan tabel 2 yang disajikan dapat dilihat bahwa nilai rata-rata literasi kelautan tertinggi diperoleh SMP 7 Pujut dengan presentase $34,41 \%$ dan nilai rata-rata literasi kelautan terendah diperoleh Mts $\mathrm{Nw}$ Prabu dengan presentase $25,83 \%$. Dalam geografis, SMP 7 Pujut berada di kota yang dekat dengan daerah pesisir dan Mts Nw Prabu berada di daerah perbukitan yang jauh dari wilayah laut dan pesisir. Pendidikan dikota memang sangat berbeda di bandingkan dengan pendidikan di desa (Anas dkk, 2015). Pendidikan di kota memiliki sarana dan prasarana pendidikan yang dimiliki cukup maju untuk menunjang proses pembelajaran sehingga siswa lebih mudah megakses informasi melalui internet. Sedangkan di desa sarana dan prasarana yang dimiliki masih sangat minim untuk proses pembelajaran. Diperoleh informasi bahwa siswa Mts Nw Prabu sangat jarang mengunjungi pantai, mereka memilih untuk melakukan penambangan dan berkebun membantu orangutan mereka saat hari libur sedangkan siswa SMP 7 Pujut memilih pantai sebagai tempat rekreasi pada hari libur. Hal tersebut yang menjadikan Mts Nw Prabu mendapatkan nilai literasi kelautan lebih rendah dari SMP 7 Pujut.

Berdasarkan hasil penelitian nilai rata-rata literasi kelautan siswa sekolah menengah pertama adalah 29\%. Berdasarkan interval kemampuan literasi sains bahwa tingkat literasi kelautan siswa sekolah menengah pertama di Kawasan Ekonomi Khusus (KEK) Mandalika, Lombok Tengah menunjukkan presentase interval dibawah $54 \%$ dengan kriteria sangat rendah.

Data tersebut menunjukan indikasi bahwa dari segi pendidikan formal, kurikulum pendidikan Indonesia yang diterapkan belum mampu untuk menciptakan generasi sumber daya manusia yang memahami dunia kelautan. Hal ini perlu mendapat perhatian pemerintah yakni Kementrian Pendidikan dan Kebudayaan (Kemendikbud) sebagai pihak yang berkontribusi terhadap mutu pendidikan Indonesia dimulai dari pendidikan dasar hingga pendidikan menengah atas. Saat ini aspek kelautan pada sistem kurikulum pendidikan nasional masih minim, khususnya pada sekolah dasar hingga sekolah menengah atas dan hanya pada pendidikan tinggi peserta didik dapat memilih pilihan yang beragam untuk mendapatkan pendidikan kelautan. 
Kemampuan literasi sains berbasis kelautan sangat penting dimiliki oleh siswa untuk dapat memecahkan permasalahan terkait dengan fenomena alam dan isu-isu sosiosaintifik yang ditunjukan sehingga menekankan siswa untuk menelaah dan memahami permasalahan terebut sehingga siswa mampu memecahkan persoalaan yang ada dilingkungan disekitarnya. Kebutuhan pendidikan kelautan akan generasi penerus yang memahami potensi yang dimiliki oleh negaranya. Aspek kelautan akan maju apabila didukung kemampuan sumberdaya manusia yang 'melek' laut. Sehingga langkah yang harus segera dilakukan yakni dimulai dengan pengenalan dunia kelautan sejak dini dan mensosialisasikan teknologi terkini pengelolaa dan pemanfaatan potensi kelautan di Indonesia.

Fenomena Negara Indonesia sebagai Negara maritime masih kekurangan sumber daya manusia yang 'melek' laut. Hal ini perlu menjadi perhatian karena lemahnya minat generasi muda untuk mempelajari dan memahami bidang kelautan. KEK Mandalika memiliki wilayah pesisir dan lautan dengan berbagai jenis sumber daya, sehingga upaya pemanfaatannya harus berpedoman pada prinsip kelestarian dan keberlanjutan. Sehingga generasi penerus dan generasi yang akan datang memiliki kesempatan untuk menikmati indahnya sumber daya laut. Untuk tercapainya tujuan ini peran pendidik diperlukan untuk mengedukasi sedikit demi sedikit menyisipkan pengetahuan kelautan dalam pembelajaran.

\section{KESIMPULAN}

Berdasarkan hasil penelitian dan pembahasan, maka dapat disimpulkan bahwa literasi kelautan siswa SMP di Kawasan Ekonomi Khusus (KEK) Mandalika, Lombok Tengah memiliki interval tingkat literasi 29\% dengan kategori sangat rendah.

\section{UCAPAN TERIMA KASIH}

Ucapan terimakasih kepada bapak Dr. Karnan, M.Si, ibu Dr. Baiq Sri Handayani, M.Pd, guru pembimbing serta murid-murid Sekolah Menengah Pertama di Kawasan Ekonomi Khusus, Mandalika, Lombok Tengah.

\section{REFERENSI}

Ali, M. (2013). Penelitian kependidikan prosedur \& strategi. Bandung: Angkasa.
Anas, A. Y., Riana, A. W., \& Apsari, N. C. (2015). Desa dan kota dalam potret pendidikan. Prosiding Penelitian dan Pengabdian kepada Masyarakat, 2(3).

Baransano, H. K., \& Mangimbulude, J. C. (2011). Eksploitasi dan konservasi sumberdaya hayati laut dan pesisir di Indonesia. Jurnal Biologi Papua, 3(1), 3945.

Cava, F., Schoedinger, S., Strang, C., \& Tuddenham, P. (2005). Science content and standards for ocean literacy: A report on ocean literacy. Retrieved March, 25, 2015.

Fauville, G., Strang, C., Cannady, M. A., \& Chen, Y. F. (2019). Development of the International Ocean Literacy Survey: measuring knowledge across the world. Environmental Education Research, 25(2), 238-263.

Greely, T. (2008). Ocean literacy and reasoning about ocean issues: The influence of content, experience and morality (Doctoral Dissertation, University of South Florida).

Handayani, B. S., \& Corebima, A. D. (2017). Model brain based learning (BBL) and whole brain teaching (WBT) in learning. In International Journal of Science and Applied Science: Conference Series, 1(2), 153-161.

Irawan, B., \& Hindrasti, N. E. K. (2018). Framework Literasi Kelautan Sebagai Acuan Pembelajaran Sains di Negara Maritim. Pedagogi Hayati, 2(1), 14-23.

Isdianto, A., \& Luthfi, O. M. (2019). Persepsi dan Pola Adaptasi Masyarakat Teluk Popoh Terhadap Perubahan Iklim. Jurnal Ilmu Kelautan SPERMONDE, 5(2), 77-82.

Kolsiana, D. (2017). Analisis Fungsi Ortogonal Empiris Dan Uji F Maksimal Untuk Mengetahui Unsur Iklim Penyebab Cuaca Ekstrim Di Daerah Gamping Pada Tahun 2009 (Doctoral Dissertation, Universitas Gadjah Mada). 
National Research Council. (2000). Inquiry and the National Science Education Standards. Washington, DC: National Academy Press.

Purwanto, N. (2010). Prinsip-prinsip dan teknik evaluasi pembelajaran. Bandung: Remaja Rosdakarya.

Rusilowati, A., Kurniawati, L., Nugroho, S. E., \& Widiyatmoko, A. (2016). Developing an instrument of scientific literacy asessment on the cycle theme. International Journal of Environmental and Science Education, 11(12), 5718-5727.

Yulianto, M., \& Putri, D. A. P. (2020). Pengembangan Game Edukasi Pengenalan Iklim dan Cuaca untuk Siswa Kelas III Sekolah Dasar. Emitor: Jurnal Teknik Elektro, 20(2), 128-133. 